\title{
MESA 2: EXPERIÊNCIAS, APRENDIZADOS E DESAFIOS NA PERSPECTIVA DE PROFESSORES E DE ALUNOS DOS PROGRAMAS DE PÓS-GRADUAÇÃO EM ANTROPOLOGIA DA UFSC, DA UFAM E DA UFPA
}

HERBERT WALTER HERMANN ${ }^{1}$

UFRGS

Mesa 2: Experiências, aprendizados e desafios pela perspectiva de professores e de alunos de pós-graduação em antropologia da UFSC, da UFAM e da UFPA.

Data de realização do debate: 09 de novembro de 2015, das 16 às 19 horas.

Composição da mesa 2: Antonela Tassinari

$$
\begin{aligned}
& \text { (Professora - Universidade Federal de Santa } \\
& \text { Catarina) } \\
& \text { Larisse Pontes } \\
& \text { (Mestranda - Universidade Federal de Santa } \\
& \text { Catarina) } \\
& \text { Raimundo Nonato Pereira da Silva } \\
& \text { (Professor - Universidade Federal do } \\
& \text { Amazonas) }
\end{aligned}
$$

\footnotetext{
${ }^{1}$ Graduado em Administração pela Universidade do Vale do Rio dos Sinos (Unisinos). Mestrando do Programa de Pós-Graduação em Antropologia Social da Universidade Federal do Ro Grande do Sul. 
Rosilene Fonseca Pereira

(Piratapuya - Mestre - Universidade Federal do Amazonas)

Rosani de Fátima Fernandes

(Kaingang - Doutoranda - Universidade Federal do Pará)

Willian Luiz da Conceição

(Mestrando - Universidade Federal de Santa Catarina)

\section{NOTAS PRELIMINARES}

Dando início aos trabalhos da tarde de segunda-feira, do primeiro dia do seminário e da segunda mesa de debates, o professor Emerson A. Giumbelli (PPGAS/UFRGS) apresenta suscintamente a composição da mesa, informando aos presentes que, por indisponibilidade de recursos, não foi possível a participação in loco de duas estudantes indígenas, uma vinculada como doutoranda à Universidade Federal do Pará (UFPA) e outra como ingressante em 2016 no doutorado na Universidade Federal de Santa Catarina (UFSC). Assim, ambas participariam por videoconferência ao debate. Todos os demais estavam presencialmente no auditório do Instituto Latino-Americano de Estudos Avançados (ILEA).

Somava-se a estes, como público, aproximadamente cinquenta pessoas ligadas ao universo das Ciências Sociais. Realizou-se gravação de áudio e registro imagético pelo Núcleo de Antropologia Visual (NAVISUAL), ligado ao programa de Pós-Graduação em Antropologia Social da Universidade Federal do Rio Grande do Sul (PPGAS/UFRGS), programa este propositor e organizador do seminário. A princípio, o evento estava organizado para falas de 25 minutos por integrante da mesa e um momento de aproximadamente 30 minutos para realização de debate junto à audiência, nessa ordem. Entretanto, por dificuldades advindas da realização das videoconferências, o debate foi fracionado em 
dois momentos, o primeiro antes da última exposição da mesa e outro imediatamente após.

Antes de adentrarmos no oportuníssimo relato dos professores e dos estudantes de pós-graduação em Antropologia, é necessário pontuar que a mesa era composta pelo dobro de estudantes em relação ao de professores, o que ensejou três caminhos profícuos: (1) a experiência daqueles ingressantes e sua trajetória seletiva anterior, até uma possível candidatura à pós-graduação; (2) os desafios quanto à permanência na pós-graduação, especialmente no que se refere às questões de ordem material e, não obstante, das dificuldades relativas à convivência e às violências impingidas nas e pelas instituições; e (3) da organização de alternativas proto-institucionais e da dependência do apoio da rede informal de relações, seja do suporte de colegas e dos orientadores, seja de relações pessoais de outra ordem e da necessidade de institucionalização de práticas para o sucesso do empreendimento.

Sublinhando estes fatores, poderíamos avançar num resumo, síntese também por parte dos professores partícipes, que apontaram, por sua vez, militâncias e desafios atrelados: (1) ao histórico dos processos seletivos diferenciados de estudantes indígenas e negros nos programas de pós-graduação em Antropologia; (2) a recuperação das lógicas próprias e entendimentos das comissões que criaram tais editais; e (3) dos desafios políticos e institucionais na ampliação e refinamento das ações afirmativas na pós-graduação.

Para fins organizativos, optamos por apresentar os relatos em caráter individual, mas dispostos dentro de blocos coletivos pensados em relação às instituições que os palestrantes estavam vinculados, ou seja, as falas serão particulares, mas a ordem em que serão apresentadas não necessariamente ocorreram conforme o delinear do evento ${ }^{2}$. O primeiro bloco de relatos segue as experiências e reflexões trazidas pela professora Antonella Tassinari, pela mestranda Larisse Pontes e pelo mestrando William Luiz da Conceição, todos vinculados à Universidade Federal de Santa Catarina. O segundo bloco de relatos considera as

\footnotetext{
2 A ordem de exposição dos relatos durante o seminário: Antonella Tassinari, professora da UFSC; Larisse Pontes, mestranda da UFSC; Raimundo Nonato Pereira da Silva, professor da UFAM; William Luiz da Conceição, mestrando da UFSC; Rosani de Fátima Fernandes, doutoranda da UFPA; e Rosilene Fonseca Pereira, mestre pela UFAM. Após o relato destes, contemplou-se um momento para debate junto ao público.
} 
experiências e reflexões trazidas pelo professor Raimundo Nonato Pereira da Silva e pela mestra Rosilene Fonseca Pereira, ambos ligados à Universidade Federal do Amazonas (UFAM). O terceiro, e não menos importante, é o bloco que contempla o relato de Rosani de Fátima Fernandes, doutoranda ligada à Universidade Federal do Pará. Por último, resgatamos notas do diálogo expandido entre o público presente no evento e as informações reforçadas pelos componentes da mesa.

Não pretendemos trazer tais pontos como uma ata descritiva, uma transcrição ipsis litteris ou realizar interpretações e mediações que extrapolam, a grosso modo, os itens tratados pelos componentes da mesa e mesmo do público que interveio na última meia hora do evento.

Neste sentido, organizamos o relatório trazendo com a maior fidelidade possível os argumentos arrolados pelas participações, assim traremos por partícipe suas colocações e, quando possível, nas notas de rodapé, recuperaremos maiores detalhes sobre os itens mencionados ou mesmo cruzamentos e acendimentos gerados em momentos distintos do seminário.

O intuito é destacar pontos que, partindo de uma posição de relatoria de um estudante do programa de pós-graduação do PPGAS/UFRGS, corroborem para as atividades do Grupo de Trabalho de Ações Afirmativas do Programa de Pós-graduação em Antropologia Social da UFRGS e seus desafios para a consecução da iniciativa.

A estratégia de confecção deste relatório visa garantir a consolidação das afirmações realizadas pelos autores sem deixar de estimular possíveis cruzamentos entre argumentos das diversas autorias (mesmo que virtuais, como no caso das estudantes indígenas) e das proposições que intersectaram o diálogo, ou vide as citações de teses e dissertações sobre o tema, experiências conhecidas em outros programas de pós-graduação e os atores sociais diversos e seus empenhos.

\section{AS EXPERIÊNCIAS E OS RELATOS PARTINDO DA UFSC}

\subsection{Professora Antonella Tassinari (professora, UFSC)}


Indicando que o processo de implantação de ações afirmativas na educação é permeado por angústias, dúvidas e incertezas, a professora ressalta seu questionamento perene se estamos no caminho certo. Advertindo que, como um caminho, há um emaranhamento de inseguranças e que estas não devem impedir a execução de programas, mas nem por isto deve-se empreender numa realização acrítica, pois sua experiência lhe ensina que mesmo iniciativas com boas intenções podem, no decorrer do processo, revelar iniciativas não tão boas assim.

Seus argumentos partem também de sua experiência desde o Grupo de Educação Indígena na Universidade de São Paulo (USP) ${ }^{3}$, quando se discutia a escolarização do ensino fundamental e médio, e das dúvidas postas se estas experiências seriam ou uma última estratégia de dominação, ou se estariam contribuindo para a autonomia e para uma situação mais igualitária das populações indígenas. Contudo, enfatiza que parte de uma experiência mais próxima à data presente, especialmente da sua participação nas ações afirmativas junto ao PPGAS da UFSC, tanto na comissão de acompanhamento das ações afirmativas da Universidade, que iniciou em 2008, e também da comissão que protocolou a proposta curricular do curso de licenciatura indígena.

A professora Tassinari articula sua exposição em três momentos: o primeiro, trazendo um breve relato do processo seletivo no programa de ações afirmativas da UFSC; o segundo, resgatando características dos editais nesses três anos de vivência; e por último, considerações dos desafios encontrados, especialmente em relação aos estudantes indígenas, porque os dois estudantes negros vinculados ao mestrado ${ }^{4}$, que compunham a mesa com a professora, poderiam trazer suas próprias perspectivas.

No primeiro momento - do processo de implantação da seleção informa aos presentes a brevidade entre a designação da comissão e a publicação do edital de ações afirmativas para seleção no pós-graduação da universidade. Período que não ultrapassou sessenta dias, da designação da comissão, em $1^{\circ}$ de agosto de 2013 , até a publicação do

\footnotetext{
Para uma consulta prévia sobre o trabalho e um histórico sucinto, consultar: <www.revistas.usp.br/cadernosdecampo/article/download/36782/39504>.

${ }^{4}$ A referência citada seria a estudante Larisse Pontes e o estudante Willian Luiz da Conceição, ambos mestrandos na mesma instituição e programa vinculado ao da professora Antonella Tassinari.
} 
edital de mestrado, em 26 de setembro de 2013 , sendo a comissão mais breve que já participou em sua trajetória como docente.

A comissão inicia a partir de uma ação de militância anterior, que se preocupava com um processo seletivo diferenciado na graduação, um vestibular indígena, e dessa efervescência surgiu a ideia de realização, também, de um processo seletivo diferenciado para a pós-graduação. $O$ empreendimento visava acolher, no ano seguinte, os egressos da licenciatura intercultural indígena e imaginava-se que o processo ocorreria aproximadamente em um ano.

Inicialmente a comissão organizou uma agenda, mapeando as experiências conhecidas: da Universidade Federal do Amazonas (UFAM), da Universidade Federal de Pernambuco (UFPE) e do Museu Nacional (MN) no Rio de Janeiro, além de recuperar informações na própria graduação da universidade e seus aprendizados. A professora, realizando uma análise, sugere que o resgate das experiências sobre a graduação dificultou, naquele momento, a implantação do processo seletivo diferenciado para a pós-graduação.

Essa dificuldade estava refletida na complexidade da discussão e dos atores sociais envolvidos, de um processo que acontecia desde 2008 na UFSC, com cotas para estudantes negros e seu debate no conselho universitário. Uma de suas defesas era a manutenção dessas cotas para negros independente da Lei de $\operatorname{Cotas}^{5}$, que não se confundiam com o segmento PBI (pretos, pardos e indígenas) estipulados por essa Lei. Então, na perspectiva da comissão, se previa o ingresso de estudantes negros de todos os segmentos da sociedade brasileira, não apenas os egressos de escolas públicas, e havia toda uma discussão trazida que poderia ser muito mais simples, eram outras questões e um outro campo de disputas que na pós-graduação estava mais acessível, mas nem por isso menos complicado.

Imediatamente após a instalação da comissão, chegara ao coordenador do curso de Licenciatura Indígena uma carta de uma estudante kaingang perguntando se havia ações afirmativas na pósgraduação em Antropologia da UFSC. Essa demanda foi relevante para acelerar o processo, estimulando a comissão a efetivar uma proposta com

\footnotetext{
5 Refere-se à Lei $\mathrm{n}^{\circ}$ 12.711/2012, disponível em: <http://www.planalto.gov.br/ccivil_03/_ato20112014/2012/lei/l12711.htm>.
} 
máxima urgência, ao invés de adiar em um ano a realização de um processo seletivo diferenciado. Com vistas a essa demanda, a comissão apresentou numa reunião a abertura de uma vaga, em 2014, para o mestrado, como uma vaga adicional ao processo seletivo corrente, pois havia se publicado o edital.

Assim, a proposta contemplava a garantia de bolsa integral desde o início do curso e compreendia que o candidato indígena deveria assinar documento de autodeclaração de pertencimento ao povo indígena, documento de reconhecimento junto à comunidade de origem seguindo uma exigência atinente ao processo seletivo diferenciado na graduação. Outro ponto sugerido era concernente à realização da prova escrita, que, em contrapartida, o candidato deveria entregar um dossiê e um projeto de pesquisa, este último com necessária arguição posterior.

Resgatando a trama de acontecimentos, a professora adverte que na reunião do pós-graduação surgiram questões e argumentos que complicavam a realização do edital, um deles questionava por que o edital não atribuía, também, processo seletivo diferenciado aos afrodescendentes. Ao alinhamento dessa questão emergiriam argumentos, que a professora Tassinari comparou com as reflexões problematizadas pela tese de Karine Pereira Goss 6 , das posições contrárias às ações afirmativas, estando presente naquele debate: (1) o argumento de que seria difícil identificar e de que deveria se ter muito rigor em relação ao pertencimento étnico ou mesmo em definir quem é negro; (2) o argumento do paternalismo, de que se deveria pensar bem antes de iniciar e se ter uma política de qualidade; (3) e o argumento de que a política poderia comprometer a excelência na educação, principalmente em virtude da ausência da prova escrita para estes candidatos.

\footnotetext{
${ }^{6}$ Doutora pelo programa de sociologia política na UFSC. Sua tese, defendida em 2008, cujo título é Retóricas em disputa: o debate entre intelectuais em relação às políticas de ação afirmativa para estudantes negros no Brasil, está disponível em: <https://repositorio.ufsc.br/handle/123456789/90867>. A autora do estudo pontua que tanto os intelectuais contrários quanto os favoráveis às políticas de ações afirmativas (AA) partilham de concepções diversas a respeito dos conceitos de raça e de mestiçagem, e possuem vinculação a matrizes teóricas que utilizam para explicar a nação, o que acaba incidindo sobre seus posicionamentos relativos à implantação de AA para estudantes negros no Brasil. Vale pontuar que três dos quatros estudantes da mesa durante suas falas ressaltaram que seu ingresso, além de pluralizar a academia, tenderia a potencializar novas problematizações e no alargamento crítico na e da própria produção de teoria em Ciências Sociais.
} 
A articulação de tais argumentos na reunião do pós-graduação lhe sugeria que a defesa da inclusão de uma vaga para candidatos negros estava colocada naquele momento com a finalidade de adiar o edital e fortalecer o argumento "vamos precisar de mais discussão", pois os modelos observados, do Museu Nacional (MN) e da Universidade de Brasília (UnB), estipulavam prova escrita para os candidatos negros.

Surpreendentemente, para a professora, sai no mesmo ano um edital novo de mestrado destinado a candidatos brasileiros com uma vaga destinada para candidato autodeclarado indígena e uma vaga destinada para candidato autodeclarado negro e que para ambos não se teria a prova escrita. Num primeiro instante optou-se pela abertura somente para o mestrado. Esboçando criticamente, enfatiza o quão injusto é emergir posições contrárias às ações afirmativas pautando-se na universalidade dos critérios de seleção, para isto mobiliza o relato lido pelo prof. Sergio Baptista na primeira mesa do seminário, do estudante Anderson Lucas da Costa Pereira (aluno do MN), sobre o quão longo é o processo seletivo que os candidatos negros e indígenas teriam passado anteriormente para acessar, ao menos, uma candidatura num processo seletivo de pós-graduação.

Observando um segundo momento expositivo em seu relato, que trata especificamente sobre o edital, pontua que a seleção no primeiro ano previa um projeto de pesquisa e um memorial. O memorial salientava a necessária contemplação sobre: (a) uma apresentação do aluno incluindo elementos que incluiriam sua autodeclaração e sua trajetória como membro de um grupo, segmento ou comunidade negra ou indígena, alvo das ações afirmativas; (b) a justificação de sua escolha pela opção de mestrado da UFSC; (c) e das questões teórico-metodológicas que trariam seu tema de interesse, definição da estratégia escolhida e definição de suas experiências prévias de pesquisa ou de ensino.

Argumentando sobre a avaliação da banca, sugere que a mesma teria pontuado a razoabilidade das candidaturas apresentadas, tanto em termos dos elementos dos memoriais quanto dos projetos apresentados. Todavia, para o ano de 2015 , substituiu-se o memorial por uma carta de apresentação, aproximadamente nos mesmo termos, mas que tornava optativa a necessária apresentação de um vínculo com grupo, segmento ou comunidade. 
Pensando sobre a permanência dos ingressantes cotistas, a professora relata uma experiência de militância junto a pró-reitoria de pesquisa da universidade, tendo em vista a efetiva garantia de bolsa de estudos, algo que não avançou e por fim, por cautela, dispuseram no edital que os dois candidatos selecionados teriam prioridade no recebimento de bolsa de estudos. Até o presente momento os candidatos foram contemplados, mas em 2016 persiste a dúvida em virtude do corte generalizado de recursos na educação.

Outro fator resgatado por sua fala adverte sobre as línguas estrangeiras. Uma das medidas realizadas exigia do ingressante um certificado de proficiência em inglês no ato da matrícula e que sua não apresentação resultaria na perda da vaga, medida mais rigorosa do que a orientação da UFSC quanto ao tema. A orientação da UFSC adverte que a proficiência linguística em idioma estrangeiro pode ser apresentada até um ano após o ingresso no mestrado. Contudo, essa medida não é unânime e, mesmo, apresenta um rigor além do que a própria universidade entende como factível, seu argumento adverte para a revisão deste critério, pois a questão da língua é um desafio.

Por fim, resgatando aprendizados a partir dos relatos de estudantes indígenas ${ }^{7}$, reflete sobre os desafios mútuos que a política de ações afirmativas engendra. Um desses pontos decorre do processo de acolhida dos candidatos, depositando como fundamental o acompanhamento e a tutoria.

Recuperando algumas falas, a professora destaca, por exemplo o relato da mestranda kaingang Josiléia, que ressalta o processo como um tencionamento na construção de si, pois em diversos momentos teria questionado sobre um conjunto de debates realizados sobre os povos ameríndios e um não reconhecimento nesses diálogos. A dificuldade só teria sido minimizada com o estreitamento dos estudos com alguns colegas e professores da universidade.

Ainda compartilhando das reflexões de Josiléia, a professora Tassinari ressalta os desafios que a estudante percebe sobre a dificuldade de alguns professores não conseguirem transpor seus ensinamentos em

\footnotetext{
7 Relatos apresentados no seminário Jornadas Antropológicas 2015. Maiores detalhes em: $<$ http://jornadasufsc2015.tumblr.com/>
} 
termos de uma universidade mais plural, em que o ingresso de estudantes indígenas e sua presença poderia corroborar neste espaço. A dificuldade pelo corpo docente decorre da não superação de noções criadas por suas posições, mesmo de discordâncias destes para com a ideia de cotas para indígenas, que não perceberiam a construção plural que se origina nesses ingressos.

A estudante ainda teria salientado que lhe parece no mínimo paradoxal a relação alimentada pela Antropologia junto à sabedoria indígena, pois se por um lado há um movimento de valorização de suas relações com o cosmo, com a sociedade indígena, o entendimento sobre a vida e a diversidade em algo instigante enquanto o indígena que fala é situado como "objeto de pesquisa" na aldeia, por outro quando estes mesmos indígenas adentram nos espaços acadêmicos, como pesquisadores, que mesmo trazendo dificuldade em certos paradigmas, mas simultaneamente novos conteúdos, acabam sendo silenciados e recorrentemente afastados destes espaços como pessoas que não são bem-vindas.

Nestes termos, a professora pontua a fala de Josiléia chamando a atenção para a questão dos afetos, pois a estudante trazia contundentemente suas angústias e sensações na pós-graduação como um ambiente inóspito para a amizade.

Em sala de aula, sentindo desconforto como pessoa, especialmente quando pretende apontar debates sob seu ponto de vista, algo não válido na universidade. Ainda pensando nesse relato da estudante, chama a atenção quanto à língua, indicando que na pós-graduação é necessária sua proficiência, mas Josiléia considera que os indígenas falam português como uma língua estrangeira, e sugere a questão: "Por que não considerar o português como forma de ingresso para nós, os povos indígenas?".

O que esse processo marcaria, para a aluna, é um processo algoz onde o indígena deve aprender além do português, que é um idioma estrangeiro, o inglês e o francês. A professora Tassinari defende a ideia de um apoio diferenciado aos povos indígenas quanto à língua. Pensa que os professores deveriam estar mais preparados para receber os indígenas, disponibilizando textos em português e devendo ter um apoio para traduzir textos em línguas estrangeiras. Outra sugestão da estudante pensa alternativas de apoio, como a proposta de seminários e 
do estímulo de exposições em sala de aula para compartilhar aprendizados, outrossim superar a estranha relação que marca duplamente os indígenas, pois "se fosse ao contrário, se eu estivesse na aldeia, meu conhecimento seria de grande valia" (resgate da fala da estudante trazido pela professora).

A professora Tassinari ressalta que os relatos das estudantes, que ouvira no seminário Jornadas Antropológicas no mês anterior, pretende evidenciar processos de relação com a diversidade, que ao fim e ao cabo problematizam os efeitos negativos desse processo de educação, gerando pessoas com baixa autoestima, timidez e solidão. Algo que não se reduz à experiência brasileira.

Aportando uma vivência que realizou na Concordia University, em Montréal/Canadá, informa sobre uma iniciativa de contratação de uma especialista em tratamentos indígenas para dar apoio espiritual aos estudantes indígenas que estavam passando também por todos esses processos naquela instituição. A iniciativa teria funcionado muito bem, pois os alunos indígenas se sentiam mais bem-acolhidos, algo que estimulou positivamente também os alunos não indígenas, que buscaram esse apoio espiritual, por, mesmo nunca tendo relatado, sentirem-se próximos às angústias e aos desafios que os colegas indígenas recorrentemente traziam.

Por fim, encerrando seu relato, a professora reforça como fundamental a questão da bolsa para os alunos ingressantes por ações afirmativas. No ano de 2015, o PPGAS/UFSC teria inovado outra vez, trazendo algumas bolsas por critério socioeconômico, algo que teve uma repercussão conflitual mesmo entre os alunos. Um dos argumentos colocados pelo corpo discente advertiu sobre a necessidade de trabalharem, ou seja, ter um emprego, o que implicaria na flexibilização dos horários de aula e da possibilidade de aulas serem ministradas à noite, para atender estes alunos. Para a professora, é perceptível uma mudança de rotina, de situações já acomodadas, pois alguns colegas não se dispuseram a ministrar aulas à noite.

Enfim, este é um exemplo de mudanças mais gerais, ainda mais se a perspectiva de bolsas diminuir consideravelmente ocorrerá um processo de flexibilização de horários de turmas. Como na graduação, se vai percebendo mudanças que são gerais em toda a dinâmica não só em 
relação a estes alunos, mas em relação a todos os demais. Essa mudança deve ser vista positivamente, para uma mudança mais efetiva e menos retórica para a diversidade.

Finaliza sua fala agradecendo a participação no seminário e o convite do PPGAS/UFRGS para o debate, e reforça uma provocação: "se nós estamos acolhendo a diversidade, que não seja para acabar com ela".

\subsection{Mestranda Larisse Pontes (aluna, UFSC)}

Ao iniciar sua fala, a mestranda resgata narrativas da primeira mesa do seminário, especialmente do proposto por Francisco Apurinã e pelo relato de Anderson Lucas da Costa Pereira, pois encontrou semelhanças com sua experiência, também do resgate de narrativas das estudantes indígenas no seminário Jornadas Antropológicas trazidas pela professora Tassinari. Argumenta que as experiências e as trajetórias são recorrentes, como, por exemplo, sentir-se geralmente desconfortável nas aulas.

Enfatizando, assim como fez Francisco, pontua que as bagagens dos ingressantes negros e indígenas estão sempre atreladas a coletividades, algo que retoma a ideia de não estarem sozinhos, ainda que nesse contexto universitário pareça que estejam sozinhos. Contudo, reforça que em todas as narrativas seria evidente uma convergência a ideia da educação como um dispositivo de transformação.

Organizando seu relato a partir da leitura de um texto escrito com antecedência, reforça que a atitude de colocar em debate a partir de densas experiências de alunas e de alunos de pós-graduação que ingressaram por ações afirmativas é no mínimo precavida, algo consonante com a luta que há algum tempo tem sido travada por movimentos sociais e de alguma maneira pela própria Antropologia.

Chamando a atenção dos presentes, Larisse busca refletir sobre dois pontos que considera sensíveis e de fato merecem avaliação, o primeiro sobre o ingresso e o segundo sobre a permanência dos estudantes cotistas nas universidades. Tratando de forma geral sobre a política de cotas e, simultaneamente, de forma pessoal, a partir dos ensinamentos em Antropologia, procura dar relevo ao contexto em que está imersa, o do programa de pós-graduação em Antropologia da UFSC, 
que, segundo a mestranda, trilha um caminho solitário, pois ainda é o único programa de pós-graduação a adotar a política de ações afirmativas na universidade.

A base para seu relato fora articulado a partir da exposição que realizara no seminário Jornadas Antropológicas (ver nota de rodapé ${ }^{\circ}{ }^{6}$ ) na mesa que fez parte, Transformações na antropologia: efeitos do programa de ações afirmativas no PPGAS/UFSC, proposta por ela e outros colegas integrantes da organização. Entende que trazer este argumento após o evento tem como objetivo refletir também sobre os pontos de vistas e trajetórias vividas expostas naquele evento, dada a experiência comum de ser cotista. A mesa foi composta pelos alunos Larisse, Josiléia, William e a professora Tassinari, e seu resgate não é gratuito, pois todas as falas naquela mesa tocaram em pelo menos dois pontos: (1) a acolhida dos selecionados e as (2) controvérsias de suas trajetórias no fazer antropológico.

Pensando a partir da acolhida aos alunos de ações afirmativas, um dos fatores que destacou recuperava as dificuldades sobre a questão das línguas estrangeiras e da indistinção, trazida pelos estudantes indígenas, sobre o próprio português como um segundo idioma. Larisse ressalta que a questão idiomática é relevante para pensarmos uma formação que se pensa democrática e inclusiva, mas que de fato exclui ao exigir a aplicação de idiomas como pré-requisito para se ser aceito na universidade, o que no doutorado se torna ainda mais grave por exigir não um, mas dois idiomas. Questionando em voz alta, coloca: "Continuamos colonizados?"

Um segundo encontro que aponta nas falas daquele seminário ressalta as controvérsias quanto ao fazer antropológico. Recuperando a história da disciplina, fundamentalmente sobre a relação fundacional na relação nós-outros, explicita de forma crítica o tratamento categorizante que demonstraria simultaneamente uma separação e uma dependência entre os sujeitos, sendo esse Outro como inferior, exótico, que encontrava-se nos primeiros estágios de desenvolvimento e que seria uma ruptura dessa Antropologia do século XVIII e XIX, por uma Antropologia contemporânea que se encontra com esse Outro como um sujeito e não um mero objeto de pesquisa. 
Todavia, coloca que o fomento de encontros com esse Outro, em espaços e momentos inclusivos que frequentemente se esbarram mesmo nos corredores das universidades, nas salas de aula, destacam ainda assimetrias que estão em vias de reconfiguração.

A estudante afirma que é assim que enxerga o programa de ações afirmativas dentro de um curso de Antropologia, como um encontro e ainda um enfrentamento de distâncias epistemológicas. Perguntando-se sobre quais os efeitos desses encontros, considera fundamental falar sobre desencontros, o de igualdade, de justiça social e a trajetória da população negra.

Enfatizando que mesmo com o avanço do quadro de melhorias sobre e para a população negra, no contexto brasileiro, ainda ocorre uma série de disparidades. Trazendo aportes estatísticos dos dados do último censo do Instituto Brasileiro de Geografia e Estatística (IBGE) aponta que mesmo com o crescimento da presença de negros e pardos nos mestrados e doutorados, em termos gerais, cruzando comparativamente a população, sua representação ainda é muito menor em relação a outros grupos, como os brancos. O que refletiria, outra vez, a situação de desigualdade da população negra. Advertindo que ainda há um longo caminho, em vias de permanência, afirma que essas políticas de inclusão são altamente importantes não apenas para a população negra, mas para atingirmos condições mais igualitárias e de justiça social.

Situando-se como mulher negra e estudante de pós-graduação em Antropologia, pontua que acessaria o racismo além do debate teórico, o que, em sentido alargado, poderia corroborar em pontos de análise críticas que extrapolam conceitos estabelecidos, aparentemente suficientes, ao ponto que se coloca no cerne da questão como um sujeito no mundo, além de uma Outra incansavelmente estudada. Entendendo que na atualidade é mister um outro olhar sobre a população negra, olhar esse também partindo daqueles que anteriormente eram somente mirados, sugere a possibilidade de um exercício calcado num desconstruir-se e construir-se constantemente, ao passo que sua presença em espaços como o do próprio evento, por si só, já indicariam uma mudança, os efeitos dessa política e, não obstante, desse movimento de um fazer antropológico descolonizado. 
Finalizando seu relato agradece o convite dos organizadores do evento e enfatiza que a promoção de um diálogo sobre a política de cotas é uma das maneiras de desestabilizar posições contrárias a essa política. O próprio debate gera um espaço para democratizar informação e que aos poucos está vingando nas universidades, em consonância com o projeto político que tem como principal objetivo endossar novas maneiras de conhecimento, fazer Antropologia a partir de outro lugar e via uma Antropologia que descoloniza saberes.

\subsection{Mestrando William Luiz da Conceição (aluno, UFSC)}

Agradecendo e parabenizando o PPGAS/UFRGS pela organização do evento, William ressalta a importância do debate sobre o tema e a urgência de avaliação das ações afirmativas na pós-graduação.

Assim como sua colega Larisse, indica que preparou seu relato de forma escrita por ainda ter dificuldade com a objetividade acadêmica. Começa justificando que a apresentação é uma reformulação de uma fala realizada para a mesa Transformações na Antropologia: efeitos do programa de Ações Afirmativas no PPGAS/UFSC, que ocorreu durante o evento Jornadas Antropológicas, no último dia 14 de outubro de 2015. Essa reformulação visa fornecer elementos para: (1) pensar a efetivação das ações afirmativas; (2) como os impactos políticos, acadêmicos e teóricos que tais políticas podem vir a resultar; e também (3) resgatar elementos da fala de outras colegas cotistas durante evento supracitado.

Apresentando sucintamente o histórico de ações afirmativas no pós-graduação da UFSC, informa se tratar de um processo muito recente, iniciado em 2013, e que, em sua percepção, demonstra afinidade com as políticas nacionais voltadas a combater a marginalização histórica das populações negras e indígenas no ensino superior no Brasil.

A efetivação dessa política passou, em 2013, pelo debate de professores e por reivindicação de alunos, especialmente dos advindos da Licenciatura Indígena, assim como daqueles alinhados às questões de outras universidades que buscam a inserção de política de ações afirmativas. 
Organizando seu relato em dois momentos, William destaca que essas políticas nacionais podem ser pensadas de duas maneiras, a primeira de um momento controverso, o estatístico, dos programas de pós-graduação que envolveram negros e indígenas, e o segundo referente ao valor simbólico e pessoal dos envolvidos.

Pensando a partir das estatísticas seria exequível avaliar que no presente momento há um crescimento de ingressos, algo significativo, mas em termos ideais bastante insatisfatório no que tange à promoção da equidade racial na universidade brasileira. Há um avanço, tendo em vista os programas de pós-graduação, mas ainda há uma luta imensa com grandes desafios mesmo se adentrarmos na experiência do âmbito da pós-graduação na UFSC, pois o programa de pós-graduação em Antropologia é o único a ter políticas de ações afirmativas nessa universidade.

No âmbito do próprio programa de pós-graduação que faz parte, adverte que foi pensada a ampliação do número de vagas de ações afirmativas, mas devido à instabilidade econômica e as incertezas em relação às bolsas de estudo resolveu-se manter o mesmo número de bolsas. Como membro do colegiado, como representante discente, pondera que seria interessante a ampliação tentando resolver a posteriori a objetivação de bolsa de estudos, sendo essencial o avanço das políticas, pois sempre existirão barreiras para sua aplicação e ampliação.

Acredita que a longo prazo o programa de ações afirmativas ajudará a esfacelar o caráter elitista e racialista branco que constitui a pós-graduação brasileira e que, todavia, isto se expresse numa virada epistemológica no conjunto das Ciências Humanas. Sendo necessário debater os dados e sua produção, mas também da própria condição de produção desse conhecimento.

Partindo de dados da Pesquisa Nacional de Amostra de Domicílios (PNAD) informa que o número de estudantes negros saltou de aproximadamente 48 mil para 112 mil estudantes; considerando apenas os estudantes negros, o número passou de 6 mil para $18 \mathrm{mil}$, um aumento de mais de 3 vezes. Analisando tais dados estatísticos do último PNAD, enfatiza que há um crescimento no número de negros na pós-graduação, o que não representaria um crescimento estatístico isolado, mas sim um contexto amplo de acesso à pós-graduação em todo o país. Ressalta que 
se observarmos os dados referentes à graduação, pois seria curta a análise que pensa somente a pós-graduação, o acesso apresenta dados que mesmo com o aumento de $27 \%$ para $51 \%$ da frequência de estudantes negros no ensino superior fica evidente que ainda persiste uma disparidade entre negros e brancos.

Relatando uma conversa estabelecida junto ao coordenador de ações afirmativas na UFSC, esclarece que desde 2007 aquela universidade acolheu aproximadamente 1500 estudantes negros. Ainda com a falta de estudos aprofundados sobre a permanência e mesmo a trajetória destes egressos, poder-se-ia pensar como um número bastante expressivo de estudantes que justifica a discussão e ampliação dessas políticas também para a pós-graduação.

Um segundo momento de seu relato articula reflexões sobre a questão simbólica, que não é menos importante do que a estatística. William afirma que esse tipo de política tem o grande poder de influenciar mudanças significativas na dimensão pessoal do sujeito que a acessa. Retoma sua própria trajetória, assim como de outros estudantes, como algo sugestivo desse impacto, pois é a primeira pessoa de sua família, para não dizer a única, graduada em universidade pública e que acessou o programa de pós-graduação de qualidade, como o oferecido pela UFSC.

Informa que faz parte da primeira geração de pessoas que pôde pensar em continuar estudando e realizar um sonho, no caso ser doutor, o que é sem dúvida matéria que culmina o esforço pessoal, de vários setores, como o movimento negro, e conquista de direitos. Trajetórias como a que está trilhando, para William, geram impactos positivos que extrapolam sua experiência pessoal, pois proporcionam construção de referências que possam também influenciar a autoestima das futuras gerações, das crianças negras, pobres e indígenas, que dificilmente veem outros grupos étnicos nesses espaços.

A ocupação do espaço acadêmico não the furta uma imensa responsabilidade e afirma uma política que reflete o reconhecimento das barreiras sociais que marcaram a exclusão de parte significativa da população brasileira do acesso à universidade. Afinal, ainda desestabiliza um espaço assentado no privilégio e nos pressupostos de exclusão histórica do racismo institucionalizado e estrutural da sociedade brasileira. 
Lembrando que a universidade brasileira tem a pretensão de construir conhecimento a partir da problemática da vida social, seria, assim, urgente reatualizar as críticas que assentam tais conhecimento e se tais políticas de inclusão favorecem a renovação epistemológica na universidade.

Assim como sua colega Larisse, retoma a fala de Francisco Apurinã, que ressaltou que a entrada de estudantes indígenas e negros não se trata apenas de indivíduos, mas se trata de acesso de coletividades inteiras. Coletividades que anteriormente eram entendidas como mero objetos de pesquisa.

Essa entrada visa municiar e produzir novas formas de abordagem e maneiras de produção de conhecimento pela Antropologia, por exemplo: na condução de olhares que possam propor questões antes não estabelecidas pela Antropologia ou pelas Ciências Humanas. Lembra que o sujeito de pesquisa sempre foi considerado representante do conhecimento-realidade que ele mesmo não conhecia em sua totalidade, e que a figura do antropólogo entraria como sujeito importante para decifrar a maneira como estes viviam na sociedade. A figura do sujeito de pesquisa, em certa maneira entendido como alienado, era recoberta pela figura mística do pesquisador, em sua maioria branco, heterossexual e de classe média, que se dirigia ao campo com o intuito de descrever sobre dados da realidade.

William informa que não pretende afirmar de forma essencialista que os sujeitos de pesquisa, agora com potencialidade de se tornarem pesquisadores, possam exercer o trabalho científico melhor nesse terreno. O que considera importante é o aprendizado e exercício contínuo de estranhar o familiar, atinente a um movimento que vem surgindo numa nova Antropologia, numa fagulha, numa possibilidade de construir uma Antropologia de fato nativa.

Advertindo tratar-se de uma postura um pouco pessimista, afirma que somente durante o caminho seria possível analisar de fato se a entrada de estudantes negros e indígenas representará mesmo transformações ou representará um novo movimento de englobamento para concepções e lógicas desse sistema, que se está procurando problematizar hoje. Rememora uma conversa com um colega de mestrado que estuda os Mbyá-Guarani, de que ouvira em campo que um 
jovem indígena na escola pode significar efetivamente, para alguns guarani, a perda de um parente, argumentando com este colega informa que esta é uma dúvida também para as populações negras.

Entretanto, adverte que a discussão que se assenta na ideia de "vamos criar uma nova elite de intelectuais negros" decorre de um debate essencialista e pouco relevante. Sua posição é que essa ideia oblitera tanto uma responsabilidade quanto uma possibilidade, a responsabilidade com que os estudantes cotistas tenham com suas origens e a possibilidade de que estes, também, possam ascender intelectual e socialmente numa sociedade marcada por um racismo vigente.

Observando ainda a experiência no seminário Jornadas Antropológicas, exemplifica um caso que ocorreu com o próprio sobre as formas operantes e dificuldades enfrentadas por estudantes cotistas. Informando que teria recebido um convite para participar do evento a partir de sua análise sobre ações afirmativas, teria aceitado; contudo, no decorrer do evento, teria solicitado uma mudança de mesa, para outra que visava debater mais detidamente sobre a relação entre pesquisado e pesquisador. A resposta obtida foi negativa, algo que entende como compreensível, mas que os argumentos elaborados dessa negação o teriam levado a pensar a preeminência insistente do racismo institucional.

O primeiro argumento da negativa ressaltava que ele teria sido convidado exclusivamente para aquela mesa, nesse caso se não estivesse contente poderia ter negado o convite. O segundo argumento de que ele teria entrado única e exclusivamente por cotas e não por qualquer requisito teórico ou acadêmico, o que lhe sugeria que estaria ali como um exemplo raro e exótico a falar somente enquanto nativo e nunca como antropólogo ou estudante de Antropologia. O terceiro argumento, "para coroar o ocorrido", foi a opinião expressa de que seu projeto de pesquisa teria pouca relevância, que é de estudar a branquitude, estudar o branco, assim informa que o episódio mostra, mesmo que parcialmente, a importância de se estudar as políticas de ações afirmativas e a consequência de negros e indígenas na universidade.

O exemplo retomado, para Wiiliam, informa sobre uma cristalização do que seja legítimo falar na universidade, de como um estudante negro e que teve o ingresso por cotas teria legitimidade para falar, desse lugar 
demarcado, algo que entente como bastante problemático e que mesmo a Antropologia não teria existido se essa regra de equivalência tivesse existido. Ressalta que o velho argumento "não sou racista" porque temos alunos negros teria sido mais uma vez acionado, agora sob a figura do "sou antropólogo e sou a favor das cotas". Mas, perguntando-se, questiona: "O que este episódio revela sob o racismo?". E segue indagando: "As cotas são suficientes para desfazer esse tipo de postura? Estamos aqui falando de cotas, de lugares marcados?"

$\mathrm{Na}$ ocasião não deixou de afirmar que não tinha qualquer problema em debater sobre a temática de ações afirmativas, pois há muito tempo debate sobre o tema, a questão é a de supor sempre um lugar marcado e a problemática de estar sempre nesse lugar. Não obstante, finaliza seus argumentos enfatizando que esse papel demarcado é enfrentado cotidianamente e que o papel do programa de pós-graduação é questionar-se constantemente sobre os enraizamentos em todos nós ainda vigentes.

Por fim, resgata uma reflexão de Guerreiro Ramos sobre o tema do negro e a vida do negro. Uma coisa seria o negro-tema, outra seria o negro-vida. O primeiro é uma coisa examinada, olhada, vista, um traço da realidade nacional que chama a atenção; o negro-vida, no entanto, é algo que não se deixa imobilizar, é despistador, profético, do qual na verdade não se pode dar versão definitiva porque é hoje o que não era ontem e será amanhã o que é hoje. Sua reflexão de fechamento é provocativa: "Queremos que esse ser multiforme, despistador entre para academia? Se for sim, ele vai incomodar muito!"

\section{MAIS EXPERIÊNCIAS E RELATOS, PERSPECTIVAS DESDE A UFAM}

\subsection{Professor Raimundo Nonato Pereira da Silva (professora, UFAM)}

Primeiramente agradece o convite do PPGAS/UFRGS para compor a mesa de debate, sentindo-se honrado em poder corroborar com a iniciativa, pois anos antes teria ocupado a cadeira de aluno no mesmo 
programa, algo que entende como fundamental para a Antropologia que aprendera e vem exercendo.

Inicia sua fala a partir de uma contextualização histórica da presença indígena na universidade que atualmente faz parte (a UFAM) e, segundo seu ponto de vista, que momento estaríamos vivendo.

Entre os anos de 1994 e 1995, a Federação das Organizações Indígenas do Alto Rio Negro (FOIRN) ${ }^{8}$, uma associação que reune mais de duas dúzias de povos indígenas da Região Norte do Brasil, teria organizado sistematicamente demandas junto à UFAM para ingresso de indígenas em cursos de graduação nessa universidade. A instituição de ensino teria recepcionado a demanda e encarregado um professor como coordenador da ação.

Este professor teria realizado diversos movimentos e estratégias para consolidar efetivamente a iniciativa na UFAM. Um dos primeiros movimentos foi realizar consulta a todos os cursos da universidade e foi acenada a possibilidade de ampliação de vagas, em $1 \%$ do total de vagas, da universidade. Informa que a recepção dos cursos foi difusa, alguns teriam recepcionado de maneira positiva, outros de maneira indiferente e alguns mesmo nem respondendo ao encaminhamento.

Dando sequências posteriores a essa consulta, a proposta teria sido aceita e aprovada pelo conselho da universidade, porém ao ser submetida à procuradoria da instituição fora agravada uma intervenção que pontuava sobre a isonomia da proposta. A administração seguinte encontrou uma brecha paliativa e a política anunciada visou encontrar cursos sequenciais de dois anos. O passo seguinte teria sido o encaminhando para a FOIRN, que acolheu sem uma revisão autocrítica do que seria essa alternativa frente à demanda inicial.

Em 1996 houve a aprovação, mais uma vez da proposta inicial, mas novamente teria sido vedada, outra vez com o argumento em relação à isonomia. Assim, o curso sequencial de dois anos foi uma dessas experiências de alunos indígenas dentro do âmbito da universidade.

Em 1998, houve o curso de formação em licenciatura e, em 2001, a formação de uma turma. A maior parte dos alunos, aproximadamente

\footnotetext{
${ }^{8}$ Para um resgate detalhado desse histórico, sugere-se consulta ao estudo de Israel Fontes Dutra (2001), intitulado Povos Indígenas do Rio Negro: construindo uma Universidade Indígena no Alto Rio Negro. Documento de divulgação da proposta de Universidade Indígena do Rio Negro.
} 
$80 \%$, deram prosseguimento a seus estudos ingressando no curso de Ciências Sociais, eram poucos os não indígenas que permaneceram no processo. A maioria sendo indígena, o que reflete algo importante de quando se cria um curso dessa natureza numa região em que, segundo os dados do IBGE, uma população de $76,4 \%$ se autodeclaram indígenas.

Em 2003, parte desse público acessa o curso de especialização de Gestão em Etnodesenvolvimento ${ }^{9}$ e alguns indígenas entram, parte destes oriundos do primeiro curso da universidade, em finais dos anos 1980. Ressaltando a crescente presença de indígenas nas cidades atualmente, o professor pontua que os fatores estão se reconfigurando.

Outro expoente importante nesse processo foram as bolsas oferecidas pela Fundação Ford. Tais bolsas garantiam aos alunos que ingressaram nesse curso a possibilidade de sua permanência. Contudo, o professor chama a atenção para a urgência na avaliação de resultados posteriores, especialmente no que ocorrera na experiência e na trajetória dessas pessoas formadas. Ressalta de forma crítica o centricionismo da universidade brasileira em avaliar e acompanhar apenas os dados que dizem respeito ao período formativo, algo que merece reflexão.

Outro ponto destacado era, durante a formação, o acompanhamento de tutores, o que corroborou na contenção do impacto da instituição frente ao ingresso e manutenção desses estudantes. Esse tutor, na visão do professor, deve ter uma linguagem apropriada, alguém com sensibilidade para lidar e entender o momento e desafios enfrentados por esses estudantes. Informando que na experiência que acompanhou percebeu que a figura do tutor realizou um trabalho de um "quase psicólogo".

Posteriormente a essas atividades, a UFAM teve a primeira ação atinente a uma política na pós-graduação. O edital do Programa de PósGraduação Sociedade e Cultura na Amazônia contemplava vagas para os indígenas. Nesse programa houve quatro indígenas ingressantes, sendo que três deles concluíram o curso, mas houve vagas mesmo que nunca chegaram a ser ocupadas pelos indígenas. Esse fator chamou a atenção do professor, pois a região detém 67 povos indígenas e ainda o acesso a essas vagas é mínimo.

\footnotetext{
${ }^{9}$ Sítio do curso: <http://laced.etc.br/site/atividades/cursos/curso-gestao-em-etno/>.
} 
Observando o processo recente, indica que em 2009 contou-se com a presença de indígenas no programa de pós-graduação, mas nos anos de 2009 e 2010 houvera apenas uma vaga preenchida em cada ano, o quadro teria se modificado apenas em 2011 com o ingresso de quatro indígenas, sendo que metade destes estavam contemplados com bolsas da Fundação Ford.

O professor comunica que o programa de ações afirmativas da Fundação Ford, no qual fez parte de sua comissão por cinco anos, tinha uma política diferenciada, pois cerca de um ano antes da entrada do candidato pré-selecionado este teria formação preliminar para que pudesse competir em grau de igualdade com os demais candidatos. Eram oferecidas condições para sua formação em idiomas estrangeiros, fornecimento de livros, matrícula, enfim, as condições de apoio material seriam ímpares.

Chamando a atenção para o número de estudantes indígenas que a Fundação Ford apoiou e a taxa de conversão em alunos formados, aproximadamente um quarto do total de ingressantes, ressalta que é necessária uma avaliação sobre o próprio programa, o que seria interessante para pensar os programas e suas modalidades de acesso. Além disso outro ponto que merece uma reflexão é a relação entre os formados e seu retorno às comunidades de partida, especialmente no acompanhamento da trajetória desses ex-bolsistas posteriormente à formação, o que era um dos objetivos do programa da Fundação Ford. Destaca que dever-se-ia refletir e avaliar constantemente: "O que formamos? Para quem formamos? E como vão atuar essas pessoas?"

Trazendo os demais anos, informa que em 2012 não houve candidatos, em 2013 houve cinco candidatos, em 2014 três candidatos e em 2015 houve oito candidatos, sendo seis indígenas e dois negros. As etnias que estão presentes são doze do Amazonas e duas de Roraima, de um universo de sessenta e sete etnias na região. Comunica que é relevante observar os contextos locais, as especificidades, para que as políticas possam contemplar as populações locais; por exemplo, na região do Rio Negro há um contingente de estudantes mais velhos, com um grau de relação contundente desses indígenas com as populações citadinas locais. Precisa-se avaliar também a relação entre as distâncias, entre os locais de origem e a própria universidade, e suas trajetórias 
políticas. Ressalta ainda que entre os estudantes indígenas há pessoas com formações diversas, alguns destes em Antropologia e Ciências Sociais.

Diante desse quadro, o professor ressalta que devemos pensar: (1) o locus da formação e inserção; (2) o locus de diálogo em Antropologia por esse público; e (3) pensar a sua trajetória enquanto um critério para a nossa reflexão nesse diálogo.

Acredita que a comunidade é extremamente importante, porque dependendo do universo desse aluno seria possível visualizar sua inserção local e seu compromisso, algo que ensejaria na criação de um curso que incentivaria a formação dos indígenas dentro de uma trajetória política no movimento e no seu fortalecimento. É necessário ainda uma avaliação contínua dos programas, também em termos de suas continuidades, mapeando o cenário e as políticas que constantemente se modificam.

Para o professor é altamente relevante pensar uma ação dessas em longa escala, em termos de 15 anos e não como apenas um período curto de formação, para que se possa fazer observação, discussão densa desses vários cenários que se apresentam paralelamente e para entrarmos em algo próximo daquilo que os Yanomami chamam de "recura", fazer uma limpeza para ver com maior clareza os objetivos de nossas ações.

A pergunta que se coloca seria: "Como instrumentalizar o conhecimento para ampliar o conhecimento tradicional?" O professor ressalta sua dúvida se estamos próximos a realizar isto.

\subsection{Mestre Rosilene Fonseca Pereira (aluna, UFAM)}

Diferentemente dos demais participantes até então, Rosilene, distante milhares de quilômetros do local do evento, participa do mesmo via utilização de tecnologia comunicacional online, ou seja, por participação virtual.

Agradecendo o convite enviado pelo PPGAS/UFRGS, enfatiza que procurara compartilhar sobre sua experiência como aluna de pósgraduação em virtude de ações afirmativas. 
Informando que seu acesso à pós-graduação fora possível somente em virtude de política de ações afirmativas, realizou vestibular específico, obtendo vaga em curso de pós-graduação em 2005. Afirma que seu ingresso fora possível apenas em virtude do processo seletivo da Fundação Ford e que, provavelmente, se não houvesse essa bolsa e o tempo preparatório pré-ingresso na pós-graduação, as condições de entrada seriam improváveis, pois residia na aldeia e desconhecia o funcionamento dos programas de pós-graduação.

Escolheu a UFAM, em Manaus, em virtude do imenso contingente populacional indígena. Detalhando sobre o processo de escolha do curso, adverte que percebia na Antropologia uma disciplina atenta para realizar um diálogo, algo próximo a sua formação na graduação, em Educação. Destaca como fundamental a orientação dos tutores da bolsa da Fundação Ford e seus aconselhamentos. Contando com um semestre de preparação, obteve um suporte em língua portuguesa, algo não menos importante.

Tratando de temas relacionados a seu ingresso, afirma que após a preparação teve um edital com seleção diferenciada num formato de avaliação apenas entre os indígenas. Durante esse tempo de preparação, debatia com os colegas indígenas e o grupo percebia que na Antropologia haveria algum diálogo. Entretanto, sua formação durante o curso the mostrou dificuldades para realização desse diálogo.

Arguindo que ficava confusa com a orientação dúbia dos professores do curso de pós-graduação, que sugeriam que ela deveria acessar o conhecimento a partir de sua própria visão, mas simultaneamente indicavam que isto deveria ser pensado segundo os autores lidos. Essa dificuldade era pela primeira vez trazida por ela, pois nunca se sentira confortável para externalizar essa inquietação. Como por exemplo: "Se esses autores já estudaram nosso povo, porque a gente vai ter que falar o que eles estão dizendo?" O que gerava confusão, assim, uma estratégia adotada por ela e seus colegas indígenas era fazer o que os professores estavam solicitando, pois estavam dentro da academia.

Sentia também a cobrança intensa do coordenador da bolsa, especialmente da exigência de falar bem o português, realizar todas as leituras, em ser uma aluna número 1. Trazendo um exemplo relata que certa vez um professor havia solicitado aos alunos que realizassem um 
trabalho a partir de suas experiências, depois do retorno perguntou aos demais estudantes e descobriu que além dela os demais tiraram notas baixíssimas, o que gerou uma dúvida coletiva, pois em seus termos haviam realizado algo muito bom, mas a avaliação do professor fora muito ruim.

De maneira bastante generosa coloca que deveria ser difícil também para o professor que teria que avaliá-los a partir da teoria antropológica e não pelo "nosso conhecimento", ao mesmo tempo em que ele pretendia auxiliar também a partir do conhecimento indígena. Pensando a partir do ponto de vista do professor, diz entender que deve haver dificuldade, pois os professores não estariam acostumados a lidar com essa situação, em entender alguns de seus contextos.

Finalizando sua fala, Rosilene relata que a dificuldade dos professores em lidar com os alunos indígenas decorre também da falta de entendimento sobre a realidade indígena. Trazendo outro exemplo, relata que certa vez argumentara em aula que, para sua etnia, quando havia uma morte, todas as coisas do falecido não eram guardadas, se desfazia de tudo; a professora argumentou com ela que isto era um absurdo, a situação a fez perceber, ainda melhor, que havia novidade para ambos os lados, tanto pelo lado dos alunos quanto dos professores.

Sua permanência ao mesmo tempo que foi imersa em dúvidas, segundo sua perspectiva, foi também positiva em entender que é necessário ter cuidados. Uma das estratégias que foram bem-sucedidas foi a formação de um colegiado indígena para tratar de assuntos, dilemas e dificuldades compartilhadas.

\section{OUTRAS EXPERIÊNCIAS E RELATOS, PONTO DE VISTA PELA UFPA}

\subsection{Doutoranda Rosani de Fátima Fernandes (aluna, UFPA)}

Assim como a mestre Rosilene Fonseca Pereira, a doutoranda Rosani participou do debate por videoconferência. Agradecendo o convite, ressalta que sua fala decorre de um longo processo de formação e acesso a ações afirmativas, envolvendo pessoas e instituições, referindo 
a participação do professor Raimundo Nonato em sua banca de seleção para a bolsa da Fundação Ford.

Informa que direcionará seu relato a partir de sua vivência como acadêmica indígena em um curso de pós-graduação em Antropologia, mas que sua formação não difere de tantos outros indígenas que partilham de experiências similares, de graduação tardia, das dificuldades em acessar uma universidade pública, da vida longe das aldeias, entre outros pontos.

Pensando a partir de sua própria formação, esclarece uma vivência situada na educação em nível superior no Brasil contemporâneo. Sua primeira experiência na educação de nível superior ocorreu no ingresso em instituição privada de ensino para graduação. Enfatiza que mesmo naquele momento seu sonho estava direcionado para a universidade pública referência em sua região, no caso a UFSC, mas que as barreiras eram inúmeras.

À época de sua formação na graduação, na instituição de ensino privada, atuava como professora na escola indígena da aldeia de Xapecozinho e destaca tanto a longa distância percorrida diariamente da aldeia até a instituição de ensino, aproximadamente 100 quilômetros, quanto sua percepção atual sobre o ensino recebido: muito deficitário, especialmente em termos de produção científica. Informa que essa bagagem é levada para a pós-graduação e que isto a obriga a estudar muito mais do que os colegas que acessaram uma boa formação na graduação.

Todavia, durante o mestrado conseguiu, em parte, diminuir essa distância formativa, pois acessando uma política de ações afirmativas específica teve a oportunidade de fazer aquilo que considera adequado: um período preparatório anterior às seleções com o custeio e apoio material e acadêmico. Como bolsista da Fundação Ford, em 2008, ingressou no programa de pós-graduação em direito da UFPA. Atualmente é doutoranda na mesma instituição, mas no Programa de Pós-Graduação em Antropologia, também advertindo como fundamental a oferta de ingresso diferenciado.

Destacando que a presença de indígenas na pós-graduação partiu de uma demanda das próprias comunidades, algo atinente a um projeto político que visa projetos de autonomia e de protagonismo coletivos das 
populações indígenas no Brasil, notadamente em fazer uma carreira universitária e se inserir em espaços anteriormente inacessíveis.

Rosani acredita que o acesso aos programas de pós-graduação é uma das maiores demandas atuais, mas que simultaneamente reside nesse acesso inúmeras dificuldades. Informando que na atualidade se tem conhecimento que um número considerável de indígenas estão cursando ou já cursaram mestrado e doutorado, mas que em sua maioria em instituições de ensino privadas, prioritariamente em virtude da escassez de editais específicos.

As instituições de ensino públicas ainda carecem de iniciativas quanto a esta possibilidade, o que, em seu entendimento, prejudica a própria instituição por não agregar a diversidades em seus programas e consolidar uma ciência ainda mais atenta aos desafios contemporâneos.

Refletindo sobre a educação de pós-graduação, conduz um pensamento refinado sobre a situação atual, algo que conduz o debate para um olhar que não se circunscreve somente à pós-graduação. Exemplificando a realidade mais próxima atualmente, a sua trajetória informa que, no Estado do Pará, ainda há uma situação característica de uma demanda que provavelmente é compartilhada por outros estados federativos brasileiros, que é um enorme gargalo no ensino médio. Dos quatro alunos indígenas no programa de pós-graduação em Antropologia no Estado do Pará, por exemplo, nenhum tem origem em comunidades próximas, todos são indígenas de outras regiões do Brasil, refere-se a sua própria trajetória, indígena Kaingang da Região Sul, e seus colegas: um Xacriabá e dois Guarani, ambos da Região Sudeste.

Entendendo que se tem avançado pouco na oferta de vagas, tanto de ensino médio até a graduação quanto daquelas de ingresso nos diversos cursos de pós-graduação, informa a iniciativa fundamental dos programas de pós-graduação em Antropologia em algumas instituições de ensino, por exemplo da iniciativa da UFPA, que, desde 2010, ano de criação do pós-graduação, oferece vagas específicas para os indígenas.

Salientando que o crescimento quantitativo de ingressos de indígenas na graduação não tem representado mudanças significativas no que se refere a políticas de permanência. As estruturas arcaicas, muitas vezes racistas e preconceituosas das e nas instituições têm gerado 
dificuldades de interação dos indígenas, mesmo com os demais colegas, reforçando o sentimento de solidão e abandono.

Abordando sobre itens do edital do Programa de Pós-Graduação em Antropologia da UFPA, Rosani aprofunda reflexões sobre os avanços e os desafios para o ingresso e permanência dos indígenas na pósgraduação, especialmente sobre a forma como a UFPA articulou essa política de ações afirmativas. O edital reserva vagas para negros e indígenas, no mestrado e doutorado, com processo de seleção diferenciado, não se aplicando provas escritas e de línguas estrangeiras - a não aplicação de exames em línguas estrangeiras decorre de um entendimento do programa quanto à utilização da língua portuguesa pelos indígenas como uma língua estrangeira. Entretanto, é exigida apresentação de documento comprobatório de pertencimento étnico, por parte de uma liderança, seja ela política ou tradicional. Além deste, é apresentado um projeto de pesquisa com realização de defesa mediante uma banca. Estes critérios têm se mantido até a data presente desde o primeiro edital, no ano de 2010.

Outro item abordado pela doutoranda ressalta desafios cuja superação é necessária em seu entendimento. Pensando a partir de suas próprias dificuldades, que lhe foram visíveis também na experiência de outros colegas indígenas, decorreriam principalmente nas deficiências na formação de graduação, formação em instituições de ensino privadas. Referindo-se especialmente à publicação de artigos, à escrita, e ao modo específico de fazer pesquisa com (e não sobre) as próprias comunidades, adverte sobre as tecnologias epistêmicas que dificultam o exercício formativo e, para a estudante, exigem uma rotina de estudos ainda maior comparativamente com os colegas não indígenas.

Exemplificando, também, sobre dificuldades mais imediatas, como, por exemplo, o acesso à informação e/ou recursos para condução da formação, Rosilene ressalta que se não fosse a sensibilidade e iniciativa da orientadora em construir o projeto à distância provavelmente não teria concluído o mestrado, tampouco estaria relatando sua experiência nesse evento.

Durante o mestrado, Rosilene residia na aldeia gavião perto de Marabá, ou seja, a 200 quilômetros de Macapá, local onde eram ministradas as aulas no mestrado. Sem acesso à internet na aldeia, 
compreende que a relação com a orientadora fora essencial para a construção da dissertação e do projeto de pesquisa para candidatura no doutorado. Essa construção à distância é uma dificuldade relevante, pois inúmeras vezes, e sem ter muito trato dos modos de funcionamento dos próprios cursos e dessa tradição acadêmica, os candidatos indígenas declinam do processo antes da inscrição para a seleção.

Sugerindo que o modo como o programa da Fundação Ford conseguiu, em parte, superar essa dificuldade foi articulando um período anterior, de nivelamento, em seu caso de seis meses, que programa uma ambientação ao círculo acadêmico, os primeiros contatos com o material de trabalho, a elaboração de um projeto condizente com o exigido pelo programa de pós-graduação escolhido etc. Assim compreende que um dos caminhos está na própria ideia dos programas de pós-graduação, na construção diferenciada de propostas de ingresso, de permanência e, não obstante, das propostas de pesquisas elaboradas pelos candidatos cotistas.

Em seu ingresso, afirma que estava realmente desorientada, pois contava com pouquíssimas iniciativas individuais e ainda menos auxílios do próprio programa. Informando que as iniciativas pessoais, de colegas e do orientador, suprem, em parte, as dificuldades no ingresso, mas que é fundamental não ficar dependente dessas iniciativas, ou seja, é preponderante que se institucionalize formas mais adequadas de recepção e acolhimento dos estudantes indígenas pelos cursos de pósgraduação, ou seja, defende a necessária construção de uma política institucionalizada.

Assim, reforça uma das ideias centrais em seu relato, de que as políticas afirmativas devem iniciar anteriormente ao ingresso dos estudantes indígenas e negros.

Outro fator destacado pela estudante ressalta sobre a dependência quase total da bolsa, pois, como em seu caso, residindo fora da aldeia de origem, e outras que se vinculou a posteriori, e mais próxima a UFPA, a bolsa era (e ainda é) o único recurso para sua subsistência. Manter-se no curso de pós-graduação sem bolsa seria inaplicável.

Examinando sobre a destinação da bolsa, para além da própria manutenção dos estudantes, Rosani informa que em muitos casos a bolsa não só mantém o estudante em questão, mas, às vezes, é destinada para 
manutenção de familiares do estudante, seja daqueles que continuam residindo na aldeia ou, como é frequente entre os indígenas, quando se move com sua família para as cidades onde os cursos estão instalados. A bolsa serve como medida básica para suas necessidades, assim reforça que seria importante articular uma bolsa específica atinente a moradia, a compra de materiais, entre outros itens. Em linhas gerais, conclui sua exposição resgatando alguns relatos pessoais. Indica que, em certo sentido, os indígenas ainda alimentam uma visão romântica em relação aos próprios antropólogos, pois, nutridos pelo histórico com a Antropologia, entendem que essa figura pode ser identifica como profissionais sensíveis, atentos às demandas das comunidades e suas narrativas, mas que isso gera uma relação que, na prática, não se confirma quando os indígenas entram na academia.

Essa visão romântica dos próprios estudantes indígenas não corresponderia à realidade vivenciada no processo formativo. Em parte, essa dificuldade não se refere apenas a essa visão romântica dos estudantes indígenas, mas principalmente em relação à formação dos profissionais destas instituições de ensino, que, imersos numa imagem clássica da própria Antropologia, desconhecem o indígena real, desconhecem os indígenas urbanizados, e ainda procuram esse "índio verdadeiro"10, menos contaminado com os males da razão ocidental.

Esse imaginário não fora apenas observado pela estudante, mas vivenciado. Indicando que em seu ingresso, quando afirmava que mesmo residindo na cidade continuava sendo indígena, era desafiada pelo desentendimento/desconfiança, mesmo dos antropólogos. O desafio para a própria Antropologia estaria em trabalhar com esse imaginário, que resiste mesmo nos profissionais da disciplina, num entendimento calcado na ideia de pureza/contaminação e desatento às demandas políticas e coletivas. Emaranhando-se a isto estaria a dificuldade na proposição de projetos de pesquisas destes novos ingressantes, derivados de intensas negociações que extrapolam os limites de uma Antropologia clássica.

\footnotetext{
${ }^{10}$ Coloco em aspas a expressão por compreender que Rosilene tenciona criticamente esse imaginário, ou seja, apenas marco textualmente com aspas a posição de sentido indicada no tom de sua fala, como um pensamento que necessita revisão.
} 
Ressaltando sobre a importância dessa presença indígena na academia e a necessidade de elaborar novas bases epistemológicas atinentes ao protagonismo indígena, instrui que um dos caminhos trilhados pela luta dos estudantes e suas comunidades entende que a construção de propostas de pesquisas é coletiva no sentido de partir das próprias comunidades, ou seja, com pessoas e suas urgências no mundo e não sobre objetos de pesquisa.

Ressaltando a relevância dessa presença, indica que há um necessário aprofundamento dessa inclusão, que não se trata de incluir para dissolver, pois a própria produção acadêmica é demandada pelas comunidades para que seja viabilizada textualmente em suas línguas, o que ressaltaria, também, um entendimento contundente: das expectativas e os compromissos que as próprias comunidades depositam nos estudantes. Não se trata de ingressos descompromissados que visam apenas um olhar imanentemente interno, seja de uma trajetória individual ou do mero cumprimento de requisitos institucionalizados. Entretanto, nem por isso essa experiência não está atenta simultaneamente ao atendimento de expectativas pessoais e às exigências acadêmicas.

Instruindo que o aumento quantitativo nas vagas de pós-graduação não foi seguido por pelo crescimento da produção e avaliação da temática das ações afirmativas neste espaço. Compreende que há a necessidade de os próprios egressos indígenas compartilharem suas experiências acadêmicas, advertindo que este seja um caminho para a construção de uma Antropologia indígena, tecendo redes que alavanquem suas próprias experiências.

Afirma que havendo o avanço de políticas de ingresso, um atual desafio são as políticas de permanência, pois as práticas ainda são eurocêntricas. Currículos e programas, na maioria dos casos, invisibilizam a presença indígena, às vezes desvalorizando-a, tratando-a como inferior, recorrentemente desconhecidas e pensadas como bloco homogêneo. Essas, para a estudante, seriam grandes dificuldades, especialmente de alguns docentes dos cursos de Antropologia.

Além das condições materiais seria fundamental a superação desse racismo institucional, pois a universidade brasileira ainda considera $o$ indígena como um alienígena no espaço universitário, nas palavras de 
Rosani: "É como se o tempo todo as pessoas olhassem pra ti e dissessem: 'o teu lugar não aqui, o teu lugar é na aldeia'”.

Finalizando sua arguição, a estudante enfatiza a necessária desconstrução dessa mentalidade colonial e também da ampliação das produções e dos impactos das ações afirmativas tanto por docentes quanto por acadêmicos indígenas para que se possa saber de que maneira se tem produzido resultados nas próprias comunidades, nas próprias universidades e na sociedade de maneira geral. Um ponto altamente relevante seria a ampliação dos espaços de diálogo, pois se tem tido de maneira geral dificuldades e o movimento indígena necessita opinar mais sobre esses editais.

Concluindo seu pensamento, indica que o movimento indígena lutou corajosamente para a abertura de portas, mas que é fundamental o acompanhamento sobre a permanência dos estudantes que ingressaram, tanto na graduação quanto na pós-graduação.

\section{QUESTIONAMENTOS DO PÚBLICO}

A primeira colocação da plateia foi realizada por um doutorando do Programa de Pós-Graduação em Políticas Públicas da UFRGS, que parabeniza os organizadores pelo debate e ressalta que é altamente significativo do ponto de vista pessoal e profissional. Identificando-se como membro da comunidade quilombola de Mostardas, argumenta que se sentiu próximo das narrativas dos estudantes negros e indígenas por compartilhar das trajetórias narradas, especialmente pelo ingresso tardio mesmo na graduação, pois precisava trabalhar, e das esperas longas entre as etapas de pós-graduação, mestrado e doutorado.

Coloca que, assim como os colegas que palestraram, percebe a importância do afeto na educação. Trazendo sua experiência de pesquisa e colocações sobre seu projeto de tese, reforça sobre a contemporaneidade do tema, que também devesse pensar na inclusão de pessoas com deficiência. Argumenta, por sua vez, emergências transversais, tais como os casos que compartilha com o público de uma criança com deficiência física que reside numa comunidade quilombola em Mostardas e de uma pessoa com deficiência que reside numa aldeia 
mbyá-guarani em Viamão, ambas no Rio Grande do Sul. Assim, o debate possibilitaria, em sua visão, o diálogo em prol da acessibilidade, não apenas na educação e a ideia de igualdade de oportunidades. Finalizando seu argumento, ressalta que a educação necessita de afetos.

A segunda colocação foi realizada pela professora Marcela Coelho de Souza (debatedora da primeira mesa do evento), que solicita o microfone para contribuir com duas inserções, a primeira referente às línguas exigidas e a segunda referente à não dicotomização dos estudos etnológicos como ou clássicos ou políticos. Lembrando que as línguas, tanto o inglês como o francês, podem ser línguas coloniais assim como ser línguas de resistência nos vários contextos em que estão presentes. Também ressaltando que os estudantes possuem experiências distintas com a utilização do português culto e isto terá também um impacto na pós-graduação, a questão das línguas excede o ponto que concerne quais são as línguas estrangeiras e quais são as línguas nativas, como, por exemplo, a língua portuguesa é uma língua estrangeira para uma parte expressiva dos povos indígenas e deve ser valorizado esse aprendizado.

Quanto ao inglês e ao francês, não se trata de simplesmente retirálas, mas defende, como no caso da UnB, o fornecimento de um curso aos estudantes que tenha como objetivo auxiliá-los a desenvolver seus conhecimentos idiomáticos. Informa que dependendo da pesquisa há outras línguas relevantes, como por exemplo o espanhol, e é quanto a isto que os programas deveriam atentar.

A segunda inserção refere-se, segundo a professora, na emergência dos indígenas no debate antropológico e a ideia de becos sem saída, a oposição entre uma Etnologia voltada para questões políticas e uma Etnologia voltada para as questões clássicas. Entendendo que esse tipo de dicotomia reduz toda a potencialidade no entrelaçamento da vida contemporânea, como, por exemplo, quando um interlocutor fala "cuidado, vocês estão irritando os espíritos da natureza e eles vão se vingar", deve-se levar isto a sério e para levar a sério deve-se compreender as relações com o Estado e também as relações cósmicas. Assim, sugere que o debate pode nos levar a sair de certos escaninhos e maneiras perturbadas para algo próximo de relações efetivas com esses interlocutores. 
A terceira participação foi realizada pelo professor Emerson $A$. Giumbelli. Especialmente a partir da experiência indígena argumenta que foi possível perceber que ocorrem deslocamentos entre as aldeias e os locais de estudo, assim gostaria de entender um pouco mais como ocorre a relação com as comunidades indígenas de origem.

A quarta participação foi realizada pela professora Patrice Schuch, que cumprimenta a mesa e ressalta dois pontos que direcionaram seus pensamentos durante os relatos: (1) da variedade das formas de institucionalização e de (2) alguma forma sobre a solidão frente aos mecanismos institucionais das cotas universitárias e mesmo nos próprios programas de pós-graduação, assim como a relação pessoal entre os envolvidos acaba, de alguma forma, suplantando esses formatos institucionais.

Em termos da variedade das formas de institucionalização pensa sobre a questão disciplinar e, trazendo o debate realizado pela manhã, sobre a mudança das formas de conceber a teoria, gostaria de saber da mesa se em suas experiências houve inserções de disciplinas novas após a criação das ações afirmativas. Uma segunda questão abordada pela professora diz respeito aos próprios projetos de pesquisa dos alunos negros e indígenas e se estes percebem se conseguiram levar a cabo modificações temáticas nas formas de construir problemas de pesquisa em Antropologia.

Por fim, informa que pretende compreender como decorre algo que apareceu nas falas da mesa sobre a questão dos afetos e da dor e questiona a mesa sobre se as formas mais institucionais de ações afirmativas preveem as relações de afetividade, assim como gostaria de saber mais detalhadamente sobre as redes informais de acolhimento e as experiências em suas universidades, ou mesmo fora de suas universidades. A terceira dimensão que gostaria de pensar é a dimensão do incômodo, trazida pelo estudante William, em que é preciso reconhecer uma questão fundamental sobre esses lugares marcados como algo desafiador que subjaz essa política.

A última participação da plateia foi realizada pela colega Valéria Aydos e questiona a mesa sobre a modalidade de preparação anterior ao processo de seleção, como, por exemplo, a encaminhada pela Fundação 
Ford, e se as universidades das quais fazem parte possuem tal mecanismo.

Relatando sua experiência na educação, em disciplinas pela Programa de Estudantes-Convênio de Pós-Graduação (PEC-PG), que oportunizam o curso de créditos antes do ingresso no curso de pósgraduação e seu aproveitamento, se isto é uma experiência realizada em suas universidades. Outro ponto que pretende compreender mais profundamente refere-se à questão sobre a valorização de saberes. Trazendo seu projeto de pesquisa, que trata de pessoas com deficiência no mercado de trabalho, percebeu que os gestores estão buscando adequações via construção de novas tecnologias, assim pensando sobre as redes informais de apoio e as tutorias, ou questiona quais são as práticas que os colegas vivenciam e que em suas opiniões poderiam ser empreendidos por uma política institucionalizada. Assim, gostaria de saber o que está sendo realizado em termos de sensibilização e da capacitação de professores e colegas nesse acolhimento.

\section{REFLEXÕES DA MESA SOBRE AS QUESTÕES REALIZADAS}

A primeira componente da mesa a relatar sobre as questões postas pelo público foi a estudante Rosilene Fonseca Pereira. Advertindo, primeiramente, sobre as dificuldade de acesso aos materiais necessários para a formação, informa que o fato de estar na aldeia e longe das bibliotecas estende em tempo o acesso a tais materiais.

Uma segunda colocação da estudante pensa sobre a questão da dificuldade em equacionar na balança o conhecimento tradicional, mais amplo e cíclico, e o conhecimento proposto na universidade, mais específico e objetivo. Essa dificuldade era em parte superada na busca de diálogo em várias linhas de pesquisa, mas pontua que mesmo entre os indígenas, os diversos grupos pensam diferente sobre certas questões e outras tratam similarmente, assim seria importante compartilhar conhecimentos no espaço universitário estimulando a troca e o debate.

Relatando uma experiência de troca e debate numa feira de que participara, a estudante reforça como a presença indígena pode corroborar para diluição de itens postos como dissociáveis. Rosilene 
informa que no presente ano participou de uma feira nacional de agricultura indígena e alguns elementos dessa feira lhe chamaram a atenção, especialmente no diálogo entre sabedorias tradicionais e conhecimentos técnico-científicos. Atentando para o relato de uma indígena do Centro-Oeste sobre a transversalidade do espiritual, da dança, da música na agricultura indígena percebia que ouvia tais entendimentos diferentemente do que os organizadores do evento, que pensavam a agricultura apenas como um acesso econômico e entendiam aquela fala como deslocada. Assim, ela e os demais estudantes indígenas mediaram esclarecimentos, pois conheciam tanto o mundo do qual a parente indígena falara e os aspectos do ambiente escolarizado de caráter universitário.

Esse diálogo oportunizado criou um entendimento para Rosilene de que há validade nas duas formas de conhecimento e que um dos caminhos para estabelecer uma relação de troca mais efetiva estaria em compartilhar com colegas da academia seus saberes e suas experiências.

Relatando que sempre brincava com um colega não indígena no mestrado, instigando-o para contar sua história, de onde viera, da origem de seus avós, e ele sempre escapava com a afirmação: "Eu não sei nada disso". Ela exclamava que ficava triste por ele, pois para os indígenas desde criança são ensinados sobre seu local no mundo. Após a convivência percebeu que o colega empreendeu uma jornada junto a sua família para saber suas origens, algo que via como muito produtivo, pois percebia que suas provocações a esse colega surtiram efeitos e levaram a caminhos não postos anteriormente.

Neste sentido, a estudante finaliza sua fala reforçando o quão importante considera tanto o seu conhecimento tradicional quanto o conhecimento acadêmico tecnocientífico.

O segundo relato que procura responder as indagações e reflexões do público foi realizado pela estudante Rosani de Fátima Fernandes. O primeiro tópico que ressalta se refere à relação com as comunidades indígenas. Relatando sua trajetória, mesmo estando há 11 anos no Pará, continua mantendo um contato próximo com suas comunidades, especialmente de seu trabalho de mais de 10 anos na Terra Indígena de Xapecó. As tecnologias de comunicação virtuais, como Facebook e Skype, são os canais de comunicação mais utilizados. Salienta que mesmo 
estando longe, em outro estado, não impede que a comunicação ocorra. Pelo menos uma vez ao ano retorna para sua comunidade, mas informa que fica difícil poder participar e contribuir mais das políticas cotidianas.

Com relação à institucionalização das disciplinas no PPGA/UFPA afirma que há várias disciplinas que são ofertadas durante o ano, uma delas foi ofertada pela professora Jane Beltrão e achou muito interessante a proposta, pois preocupava-se acerca da diversidade cultural e da possibilidade de construção de um Brasil plural, pensando os povos indígenas e os povos quilombolas. O programa fora criado com essa ideia e a professora Jane Beltrão, que foi uma das idealizadoras do PPGA, já vinha propondo essas atividades.

Mesmo no mestrado em Direito, Rosani fez várias disciplinas na Antropologia como ouvinte, e outras ela aproveitou, sentindo-se incluída. Ainda em relação às comunidades, ela tem uma militância junto aos Gavião Parkatêjê, mesmo não residindo mais na aldeia gavião, continua assessorando três associações indígenas. Mesmo não estando vinculada com nenhuma instituição, acaba orientando e coorientando estudantes da Licenciatura Intercultural e os estudantes indígenas que estão nos cursos das universidades federais e privadas.

O que percebe é que, infelizmente, ainda há muita dificuldade quanto aos instrumentais da pesquisa nesses cursos e tem procurado auxiliar os estudantes indígenas da melhor forma possível, recebendo as pessoas para almoçar em sua residência, para acessar a internet, entre outros. Acredita que fora da aldeia é possível fazer muitas coisas também.

Com relação ao projeto de pesquisa, ela realiza um estudo junto aos Tembé-Tenetehara, que é um grupo tupi que mora na região nordeste do Estado do Pará e que há 15 anos luta pela retomada de seu território tradicional e do pertencimento étnico, que eles haviam deixado em suspenso desde o início do século passado até 2003, em virtude da submissão a processos coloniais. Catequisados pelos Capuchinhos italianos, desde 1920 não se ouvia mais falar dos Tembé-Tenetehara de Santa Maria do Pará, hoje estão em duas aldeias que são divididas pelo Município de Santa Maria do Pará. Sua investigação tem o intuito de compreender com eles como o processo de escolarização contribuiu para essa invisibilidade, esse silenciamento étnico, e de que maneira essas 
políticas contribuem, ou não, para essa luta na retomada do território e do pertencimento étnico.

Pensando sobre a indagação atinente aos afetos e às redes informais de acolhimento, relata que há uma experiência informal na UFPA que não é institucional e que nasceu com o protagonismo indígena. Os acadêmicos indígenas se associaram formando uma rede informal de acolhimento a novos estudantes, por exemplo, sua casa em Belém recebe pessoas de outros povos. Essa associação iniciou um diálogo com a universidade para a criação de uma política institucional, mas o empreendimento não surtiu efeito. Relatando que durante dois anos realizaram caravanas do vestibular nas aldeias com o intuito de divulgar os processos de seleção, mas a instituição não tomou isso com uma política e a universidade não acolheu a proposta. A dificuldade para ela decorre do entendimento de pessoas na própria instituição de que a universidade sempre está fazendo muito pelos indígenas.

Essas redes de apoio vão acontecendo mais em termos dessas associações indígenas e das comunidades indígenas e o parentesco que é o pertencimento étnico, de manter as lutas e os enfrentamentos, do que via uma política institucionalizada atinente às formas de acolhimento e permanência dos estudantes indígenas que ingressam na universidade. Para finalizar, Rosani agradece outra vez o convite e espera ter contribuído para o debate.

Estimulada pelo relato da colega, Rosilene solicita ao organizador da mesa mais um momento de fala. Abordando sua posição quanto à questão da relação com a comunidade, relata as dificuldades de retorno, após formada. Voltando para sua aldeia de origem, depois de formada, fora contratada como antropóloga, mas adverte que a experiência foi breve, pois percebeu, a partir de dentro do órgão indigenista, o despreparo e falta de vontade de seus gestores. Solicitando sua saída, procurou articular um trabalho organizando um coletivo junto com outros indígenas que voltaram a São Gabriel da Cachoeira e que não tinham vínculo nenhum com outras instituições ações para efetivar mais atentamente as demandas das próprias comunidades. Organizaram pequenas exposições junto aos agricultores indígenas, trilhas ecológicas, entre outras ações. Informando que as comunidades se sentem valorizadas com a ação, mas não é algo fácil, pois com esse tipo de ação 
se acaba obtendo muitos inimigos. Ressalta que a iniciativa de estudar é algo relevante, pois a ajuda a compreender melhor o que é o Estado, aprendendo nos dois lados, nos dois mundos. O nome do grupo é Água, Terra e Floresta por uma vida saudável e tem por objetivo realizar atividades em escolas, em centros comunitários, todos próximos a centros urbanos.

O terceiro componente da mesa a contribuir com reflexões é William Luiz da Conceição. Ressaltando que há um contexto bem diferente das ações afirmativas na graduação e na pós-graduação, informa que o primeiro foi articulado pela participação de movimentos sociais e de luta quanto a políticas de acesso e permanência de estudantes negros na universidade, que corroboram em pautas relevantes como o acesso a creches pelos filhos das estudantes negras e outras demandas, enquanto o segundo ainda é muito recente.

No ambiente das Ciências Sociais, em 2010, na graduação, foi inserida uma disciplina obrigatória sobre estudos afro-brasileiros e que tem por objetivo pensar sobre essa questão no ambiente da universidade - é a única que articularia especificamente sobre essa realidade. William destaca que houve um impacto da entrada dessa disciplina na graduação, mas, por exemplo, na pós-graduação, que não ocorrera a entrada de disciplinas novas, a situação tenha permanecido a mesma.

A questão seria pensar efetivamente sobre a inclusão, pois não bastaria o ingresso de estudantes negros e indígenas sem a alteração do status quo acadêmico. Descrevendo uma experiência pessoal, o estudante relata um caso ocorrido com outra estudante cotista. Em seu ingresso no mestrado e atento à inclusão, William e os demais colegas convidavam com frequência uma colega indígena, mas que geralmente desviava dos convites, algo que lhe intrigara. Num primeiro instante tanto ele quanto os demais colegas se questionaram por que da atitude arredia dela, afinal o convite visava sua inclusão e uma boa convivência. Contudo, algum tempo após as negativas, a colega indígena relatara para ele que não o acompanhava em virtude do próprio alimento e do ambiente onde eram servidas as refeições, entendidos como ruins e desconfortáveis. Assim, o estudante, revendo seu primeiro entendimento, discorre sobre as dificuldades atinentes ao que seja inclusão, afinal, nunca ele e os demais mestrandos não teriam se preocupado em ir ao local onde a 
colega indígena apreciava almoçar. Assim, William problematiza que a dificuldade de pensarmos inclusão procede dessa perene necessidade de trazer o diferente para o "nosso mundo".

Ampliando seu argumento sobre a questão da língua, informa que os discentes tentaram alternativas para superar tal dificuldade com a criação de grupos de estudos, mas reflete que a iniciativa não institucionalizada esbarra nas possibilidades e vontades ligadas às pessoas, neste sentido defende a ideia de institucionalização de práticas de aprendizado para os estudantes que ainda não detêm a proficiência nos idiomas estrangeiros. Salienta que o aprofundamento no aprendizado de idiomas é algo fundamental, mas que é relevante também entender a trajetória dos estudantes, assim não se trata de negar esse aprendizado, mas compreender que há sim um desejo compartilhado para a fluência, ou seja, dever-se-ia apostar na alternativa de aprendizado durante o processo e não como um fator que exclua ou cause um mal-estar.

Por sua vez, o professor Raimundo Nonato Pereira da Silva inicia seus apontamentos justamente pela questão idiomática, chamando a atenção para o fato de que há diversidades contextuais. Exemplificando a partir da sua experiência de trabalho junto às populações indígenas, esclarece que no Norte do Brasil existem grupos indígenas que dominam bem o inglês e/ou francês devido aos processos coloniais, especialmente nas Guianas, pergunta-se assim: "Como essas línguas potencializariam e ampliariam sobre o mundo, sobre a realidade, e ao mesmo tempo os colocariam em contato com outros povos?" Para o professor esse seria um efetivo desafio a ser colocado.

Observando as seleções dos programas de pós-graduação que relataram suas experiências, informa, assim como a professora Marcela Coelho de Souza, que há uma falsa dicotomia entre a forma clássica e a forma mais política. Sugere que quando se pesquisa sobre a cosmologia há consigo formatos próprios desses grupos que aproximam o debate político geralmente a partir de seus sabedores.

Um outro desafio para o programa do qual faz parte seria os deficientes auditivos, que estão acessando os programas, pensar que a inclusão coloca desafios ao corpo docente inclusive. A questão sobre a criação de disciplinas indica que devemos pensar sobre como motivar os estudantes a cursá-las, em como aproximar e mostrar a importância 
dessas disciplinas, assim, entende que a orientação tem papel fundamental nesse processo, ou seja, não basta se criar as disciplinas.

Informa que a Antropologia é somente um campo dentre vários que está disputando o campo da educação e da questão indígena. Dependendo desse ângulo pode-se assumir um esforço pouco produtivo de fechamento ao diálogo com outras ciências, em parte pelo reconhecimento externo de que a Antropologia acaba tencionando críticas que incomodam outras áreas, ou mesmo devido a um falso dilema que a Antropologia é detentora do direito sobre os indígenas, mas esses caminhos são limitadores.

Ressaltando que enxerga um dos dilemas atuais da UFAM nesse diálogo sobre ações afirmativas não apenas de sujeitos no mundo, mas de um confrontamento de instituições, o que é expressivamente político. Indica que o dilema agrava tensões de complexa solução, pois coloca em pauta simultaneamente uma estrutura universitária hierárquica e vertical para dialogar com instituições comunitárias horizontalizadas. Assim, deve-se observar que são duas estruturas que estão buscando um diálogo, uma delas pretende se precaver e a outra se defender contra formas possíveis de sistemas de educação que tentam capturar seus pares.

Respondendo a questão da professora Patrice Schuch, argumenta que a questão da institucionalização deve se passar por uma política, de um campo de negociação interno de cada universidade que tem seu próprio horizonte, sua perspectiva, seus embates, mas questionando-se "Por que tem que se insistir na institucionalização?". Na sequência, o próprio responde: "Porque as pessoas passam". Afirmando que nos últimos anos estamos vivendo intensamente a dependência do voluntarismo, da boa vontade, algo que fez avançar enormes conquistas, em sua maioria não replicáveis, deveríamos atentarnos na procura de outras saídas que estimulem e definam modelos institucionalizados para as ações afirmativas. Trazendo exemplos próximos a sua experiência docente na UFAM e da recepção de comunidades indígenas naquela universidade, ressalta que a complicação pode ser minimizada pela institucionalização.

Abordando o tópico questionado sobre os projetos de pesquisa, depõe que estes vêm trazendo desafios, por exemplo se pensarmos na 
questão da língua, quando um estudante indígena que possui conhecimento da língua, mas o orientador não tem. O desafio da língua inglesa e francesa pelos alunos é factível com o entendimento de que há um desafio da língua indígena pelo corpo docente, assim subverte-se também a questão.

Por fim reflete sobre o ponto atinente à afetividade na educação. Dispondo de seu conhecimento entre os Yanomami, ressalta que para eles é uma tortura passar muito tempo fora de sua comunidade, ainda mais quando ocorre uma cobrança e não se consegue encontrar um canal de saída. Ressalta que é importante se dar conta disso e como poder-se-ia trabalhar, pois há uma responsabilidade das instituições educacionais quanto a estes itens.

A estudante Larisse Pontes retoma sua fala abordando a questão posta pela professora Patrice Schuch sobre a institucionalização das ações afirmativas, especialmente sobre a criação de disciplinas. Destaca que na UFSC há uma preocupação de algumas professoras, como a professora Ilka Boaventura Leite e a professora Miriam Grossi, que vêm pontuando a partir dos Estudos de Gênero a proposição de diálogos interseccionais.

Apontando uma experiência profissional como docente, informa que há uma especialização em gênero e diversidade na escola, na qual faz parte como professora tutora justamente de um módulo que trata de raça, racismo e etnicidade, algo que vê como positivo não apenas em virtude da disciplina em si, mas porque juntamente com outro colega foram os primeiros tutores negros desse curso, ou seja, a participar num caráter mais diverso.

Pensando sobre a questão do idioma, achou interessante a proposta da professora Marcela Coelho de Souza, não só em virtude do apoio na formação, mas também em relacionar ao estudo que se realizará, ou seja, entender qual língua é a mais importante para o projeto de pesquisa que o estudante pretende realizar.

Em relação às cotas universitárias, adverte ser fundamental um acompanhamento estendido dos egressos, mesmo com o mercado de trabalho, algo próximo do debate sobre a profissionalização dos antropólogos e que de alguma maneira gera embates principalmente a 
partir de algumas entidades que se dizem representativas dos antropólogos.

Concluindo, informa que assim como outros colegas negros não dispôs de uma preparação anterior, de seis ou mais meses, mas buscou alternativas, como, por exemplo, uma especialização que realizou em Antropologia como uma etapa preparatória importante a seus estudos.

Encerrando o debate no evento, a professora Antonella Tassinari expõe dois fatores, o primeiro atinente a segmentos que não são atendidos pelas cotas e que a UFRGS poderá ser pioneira na inclusão desses grupos, tais como o de pessoas com deficiência, o segundo pretende chamar a atenção do público quanto ao recado elaborado pelos estudantes que participaram da mesa, que, em seu ponto de vista, foram indulgentes frente às estruturas arcaicas e elitistas da universidade brasileira, algo que ficou sensibilizada e informado por ouvir nesses relatos a atenção dos próprios estudantes quanto às dificuldades e limitações dos professores e da própria instituição, algo que agradece pelo aprendizado.

Recebido em: 14/11/2015 * Aprovado em: 14/12/2015 * Publicado em: 31/12/2015 